\title{
Gesture in Painting: Problems in Semiology
}

\author{
ANDRÉ CHASTEL
}

In February 1602 , Caravaggio was commissioned to paint a large picture of Saint Matthew and the Angel for the altar of the Contarelli Chapel. Upon delivery a few months later, the work was refused 'con dire che quella figura non haveva decoro nè aspetto di Santo' ('they said that that figure had neither the dignity nor the bearing of a saint'). ${ }^{1} \mathrm{~A}$ new, slightly taller picture was hastily completed and installed over the altar by the end of the year. The first painting was destroyed in Berlin in 1945, the second still hangs in the chapel. A comparison of these two works offers an occasion that could hardly be considered more favourable for understanding one particular artist's passage from an intimate, familiar style to a formal one. In fact, the gulf between the two compositions has frequently been discussed in this context, but the comparison is equally useful for illustrating the importance of gesture in the organization of the two images and for delineating the problem - or the range of problems that bring us together today.

In the first picture (fig. 1), the angel, pressed against Matthew, guides the hand of the Evangelist. The focal point of the image is furnished by the encounter of the two hands on the book (written with exceptional care in Hebrew) around which the composition gravitates. In the second painting (fig. 2), all intimacy has disappeared. The angel and Matthew belong to two spheres that are barely tangent; here again, an essential role is accorded to the two gestures: on one side the large, raised hand holding the pen and, on the other, the fingers displayed in the action of computatio. Since both works use gesture as central elements of narrative, a change of approach necessarily entails a new manner of defining those gestures. In the first case, the quite unconventional gesture had a familiar character and gave birth to a direct, popularizing image, while in the second the hierarchical relation is re-established by returning to the most traditional, most codified gestures: the hand on the writing table and the computatio. Caravaggio seems to have thought: 'they want something banal, that's what I'll give them!' Nonetheless, he artfully used the ele- 
2 / Renaissance and Reformation

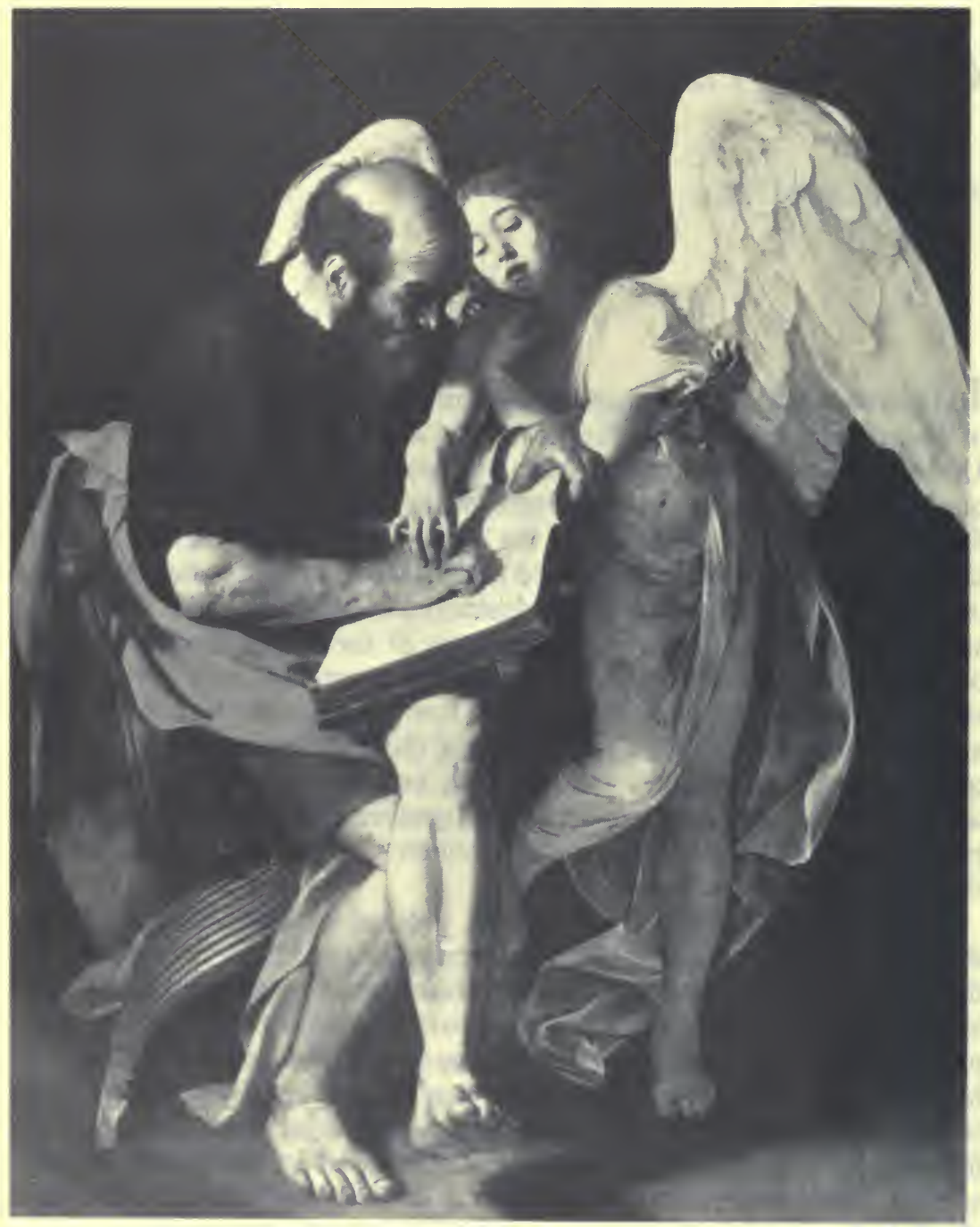

Fig. 1: Caravaggio, St. Matthew and the Angel (Berlin, Kaiser Friedrich Museum; now destroyed) 
Renaissance et Réforme / 3

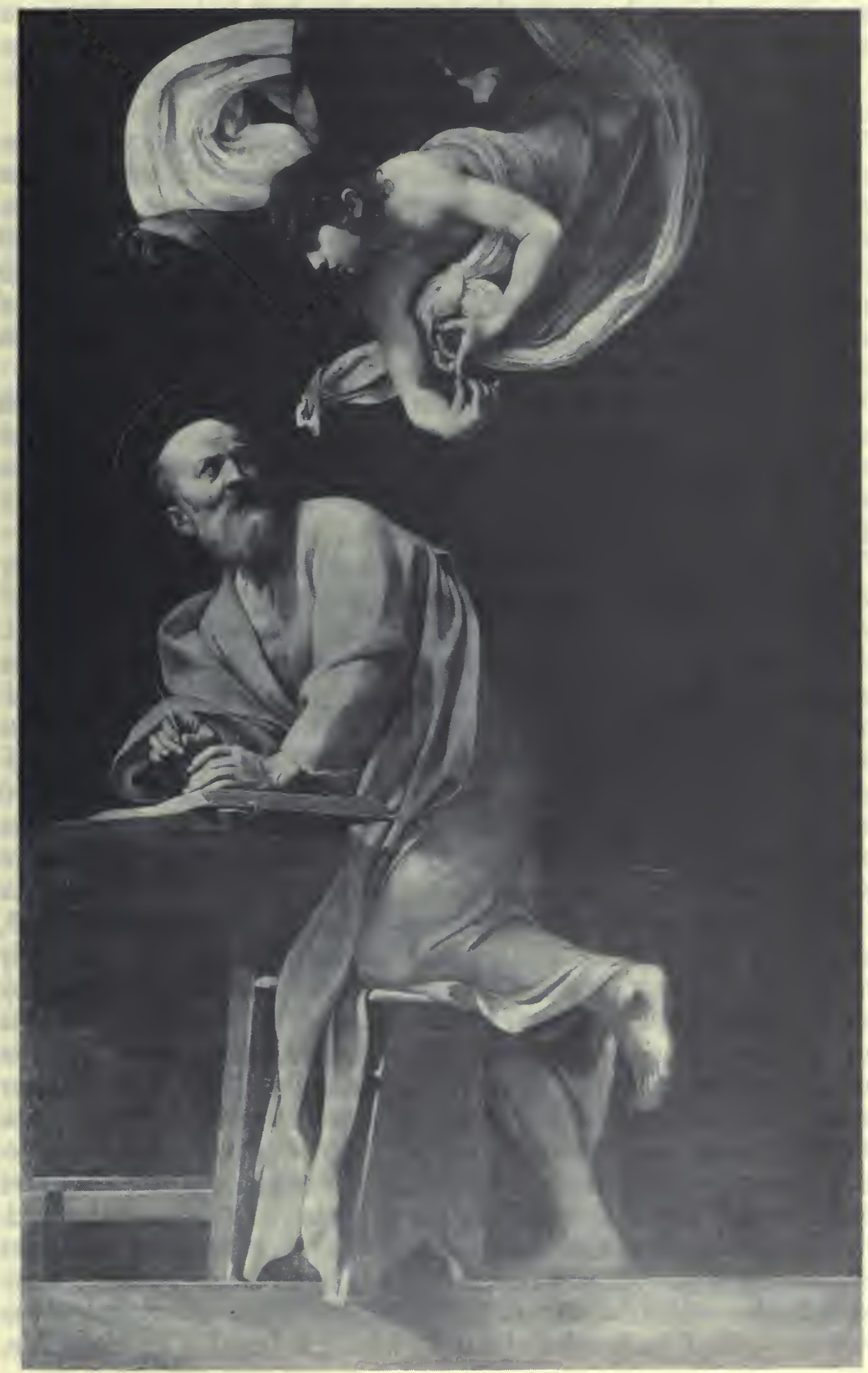

Fig. 2: Caravaggio St. Matthew and the Angel (Rome, S. Luigi dei Francesi) 


\section{4 / Renaissance and Reformation}

vated emplacement of the work to produce an impressive di sotto in sì composition and introduced the details of the book and teetering ladder to accompany the suspended hand. The computatio is justified because the text dictated to Matthew is the genealogy of Christ: qui genuit, etc. Everything has its place in this construction.

This example directs us towards the two main problems concerning gesture in art. One is epistemological: where it is clear, as it is here, that the reading of a painted work can and must begin with the gesture, is it necessary to conclude - as certain modern authors do - that, in painting, as in all domains dependent on semiology, the purely artistic point of view should be subsidiary to that of communication? In other words, does the kind of analysis that interests us presume a psycho-socio-biological interpretation of art, a reductive conception of the representation?

On the other hand, Caravaggio's clash with the patrons of the Contarelli Chapel presents a problem that historians seemed to have somewhat ignored until now: how can several systems of gesture coexist? How does codification operate in this realm? Or, is the Renaissance a period of codification or one of change in gestural language?

These questions are so important and so broad that I might pompously have entitled this lecture: 'Prolegomena to a critique of gestural language.' Indeed, we must step back from the customary approaches of art history. The consideration of style must be set aside, provisionally, in favour of an examination of forms treated as specific points of passage from the signifier to the signified. Such a procedure is justified for one simple reason - far too neglected in my opinion - which I would like to develop first. In the representation of the human figure, the expressive gesture is the preferred bearer of the psychological message, or, more precisely, it has the greatest responsibility for the affective capacity of the composition. Whether we approach a work of conventional though exquisite devotion such as the ravishing Madonna of the Stone Carvers by Andrea della Robbia (1475, Bargello), or a dramatic altarpiece such as the Madonna d'Ancona by Titian (1520, Ancona, Museo Civico), or the Madonna da Foligno by Raphael (1514, Rome, Vatican) which preceded it, a technical analysis makes it evident that the main point of the composition is the ordering in space of figures linked to one another by attitudes and gestures. If we linger over this idea, what informs and impresses us in the work-sometimes with lasting effect - becomes evident very quickly. Those movements of tenderness or excitement are perceived without effort; the passage to the signified happens rapidly, directly, almost unconsciously. We are convinced, instinctively, that communication has taken place smoothly, without hesitation, as in daily life. However, this is often an illusion. In finely accomplished works, well-rendered design confers upon gesture an obviousness which makes us forget the effort necessary for its realization. 
All great artists have affirmed that the observer must be made to forget the craftsmanship. Yet, it is precisely the 'how' of the thing that interests us and which induces me to begin with a somewhat fastidious analysis of the mechanisms at work.

When the subject is well-known and the viewer recognizes it by a few conventional cues, then the gestures are given a rapid 'reading' by the spectator, who lingers only if he is curious to examine how the artist was capable - or not - of varying attitudes in introducing pleasing innovations. Conversely, if the scenario happens to be unknown to us, either for want of a title or renown, or quite simply because the work is from another culture, our reaction will begin with the gestures as the most useful expressive reference points. Experience proves that sometimes we rely exclusively on those psychological signals. The specialists of iconography would be well advised to beware of that reflex which can just as easily mislead us as it can orient us.

Let us take, for example, the famous composition of Dirk Bouts (Brussels) painted around 1470 (fig. 3). The scenario is not familiar to everyone: it is the ordeal by fire by means of which a widow sought to obtain justice from the Emperor Otto for the unjust execution of her husband. The story is found in the Golden Legend (chap. 178, on Pope Pelagius; it is, in fact, a survey of the Istoria lombarda). The synthetic image of the widow holding the two rather surprising objects (red hot irons) suggests something along these lines. But let us examine the cycle of gestures around her. The Emperor holds the sceptre in his right hand. But what is he saying with his left hand? Is it a favourable reception of the widow's plea, or an affirmation of his mistaken judgment? Is his left hand moving forward (doubt), or rising to his breast (assertion)? The witness nearest to him makes a conventional gesture of surprise; on the left the counsellor dressed in black makes a gesture of indignation and takes the arm of his neighbour, a gentleman whose gesture seems reproving or defensive. And, finally, we notice the impassivity of the attendants in the imperial entourage. The scene thus condenses a certain number of conventional definitions. We are obliged to explore and analyze them in order to discover the overall meaning.

When the theme is simple and accessible, the gestural language coalesces with the meaning; the code works. Naturally, the frozen scene of judgment could have been developed into a violent compsition, cruel and pathetic. The Martyrdom of Saint Matthew by Caravaggio (fig. 4) offers a rather surprising example of such turbulent style. It is a whirlpool of figures, all carried to the height of expressivity in gesture. Aggression, abandonment, horror, surprise, terror, are all depicted through unusual and prodigiously effective pictorial means; varied projections that either spotlight movements or drown them in shadow. 


\section{6 / Renaissance and Reformation}

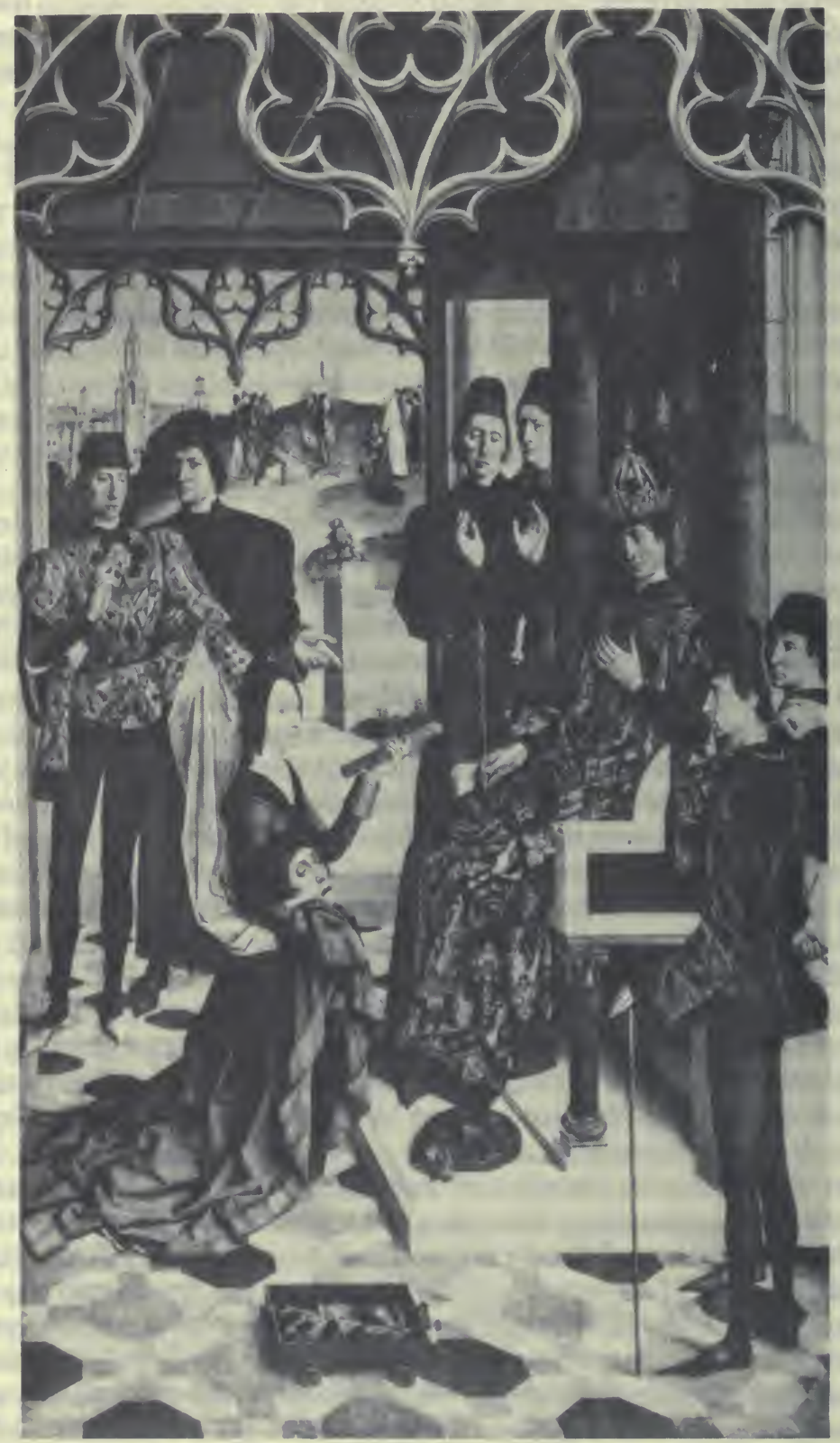

Fig. 3: Dirk Bouts, Justice of Emperor Otto III (Brussels, Musées Royaux des BeauxArts) 


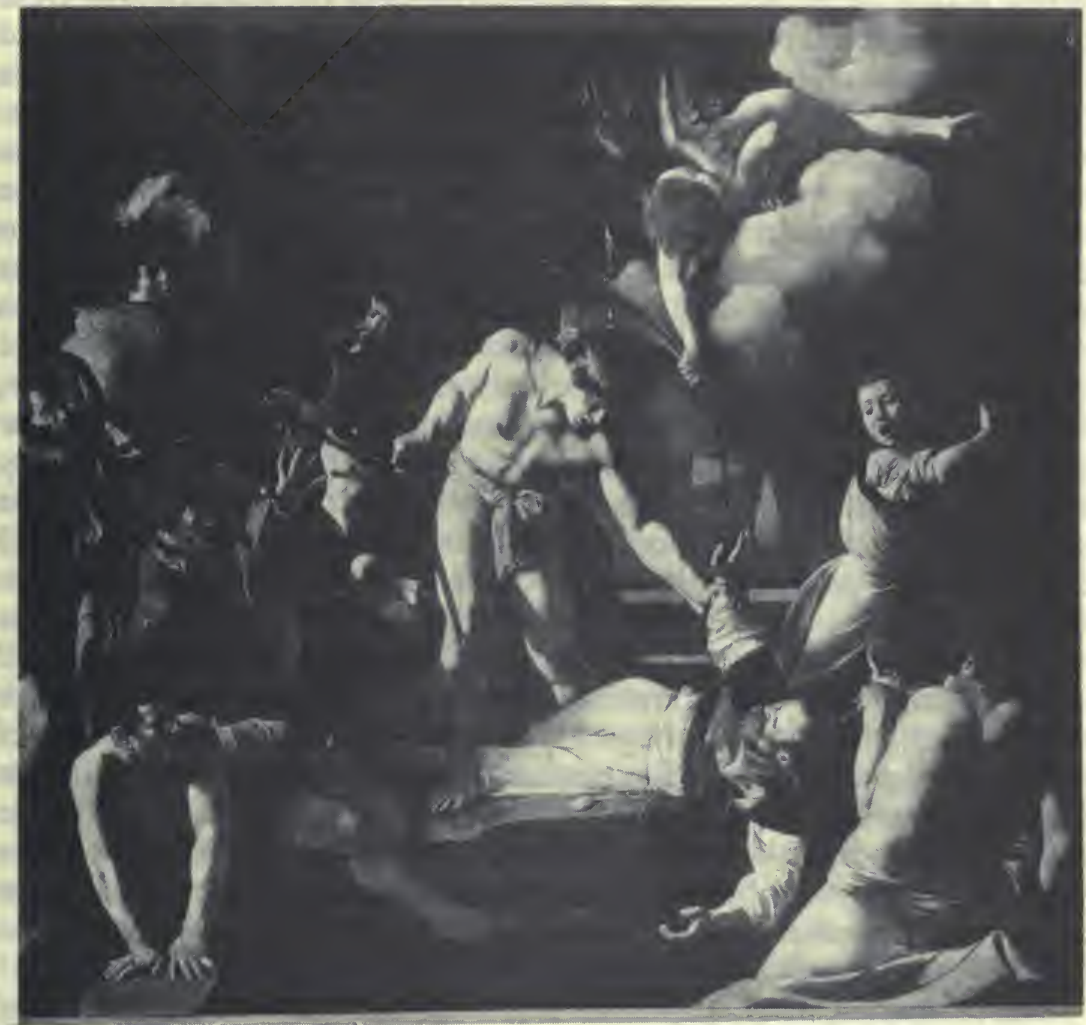

Fig. 4: Caravaggio, Martydom of St. Matthew (Rome, S. Luigi dei Francesi)

What are we to conclude from these observations, which could be multiplied infinitely? An extremely simple fact which I would like you to keep foremost in your minds during the rest of this presentation. Whether the style is condensed and static - which entails a rigorous codification or unfettered and dynamic - with a formidably enriched repertory - the painted composition remains nonetheless a 'symbolic form.' The expressive gestures are one of the two major means available to the painter to arouse reactions comparable to those in real life. Next to perspective, which exercises a magnetic pull on our vision of space, we must consider the physiognomic effect based essentially on gesture. It is a second perspective, a psychic perspective, psycho-physiological if you will, whose modalities must be explored. 
For a third of a century the humanities have been dominated by a linguistic model. The history of art, which with Riegl, Wölfflin, and others was the up-to-date discipline around 1910-20, fell in the years that followed and is today in a state of confusion which is surely transitory. The dogmatic point of view, according to which language is the basis of all consciousness, so much so that all mental processes must be interpreted as a function of the laws of discourse, is beginning to ease. To counterbalance this view, it is indispensible that we discover the existence and the modalities of non-verbal communication. In response to the 'over-intellectualized' description of mental activity as a function of language, there is an 'under-intellectualized' presentation with multiple, furtive or evasive manifestations based on movement. This point of view has direct bearing on the language of gesture. But we are only at the very beginning of this reflection; the mass of phenomena extending from the unconscious reflex to the orator's tic, is far from being sufficiently explored. One particular difficulty arises from the nature of the documentation. Since the second half of the last century, photography has slowly enriched our storehouse of gestural images; nonetheless, we still need that immense figural archive made up of the world's art. We have the feeling that we could write a fairly honest history of the gestures of repulsion or greeting from Egyptian reliefs to the present, provided we always identified the code. But we can also see that we could never seriously construct the history of the kiss or the slap, because these are not, in the forms familiar to us, universal manifestations of affection or contempt. Moreover, every gesture has not received equal treatment figural documentation is selective.

The celebrated study by Charles Darwin, The Expression of Emotions in Man and Animals laid the foundations of the strictly 'physiological' explanation of gestures based on reflex movements. In it, the great scholar took care to show that his research did not coincide with that of the art historian: 'I thought I could count on getting plenty of help from the great masters of painting and sculpture who are such penetrating observers. So I studied photographs and prints of many of the wellknown works. Apart from a few exceptions, however, they were of very little use to me.'2

A few years later, when Wilhelm Wundt devoted one of the volumes of his Völker-psychologie to the language of gesture, he relied in a curious manner on a Neapolitan work illustrated by Gigante, of which we shall say more in a moment. ${ }^{3}$ It is probably that dependence which explains the point of view developed in an article by Salomon Reinach entitled 'The History of Gesture.'4 In it, Reinach forecast that by 1950 at the latest, thanks to the diffusion of instantaneous photography, there would be an immense increase in the repertory of gestures in art. Mid-century 
has come, it is even somewhat behind us. The study of expression based on Darwinian psycho-biology and using the technical resources of photography has known some success in the works of Desmond Morris, in particular in Man Watching ${ }^{5}$ without being of much value, however, to the art historian. And the study of the 'language of gesture in art' announced by Reinach has waited a long time to begin to take form. The conference on "non-verbal communication" held at Cambridge in 1972 may be considered as a good starting point. ${ }^{6}$ The fact is that the study, as was foreseen, becomes more and more complicated as it unfolds.

Do we receive more enlightenment from the semiologists? In principle yes, and in fact no. Always for the same reason. In contrast to, or at any rate as a complement to the naturalist explanation of expressive gestures as an architecture of reflexes, the 'cultural doctrine' insists heavily on the role of convention and thus of social definition of all gestural language. The debate is so fashionable that I shall beg off mentioning names so as not to slight anyone. We leave behind the realm of vitality and expressive spontaneity for that of communication. The relationship of speakerlistener in verbal activity is used as a model for the non-verbal relationship of emittor-receptor, which presupposes the existence of a code in order that the experiencing of the message have a meaning. Grimaces imply a register of comical expressions; caricature has its indices, for example. Unfortunately, or perhaps fortunately, the code is the same for poster art, the television announcer, the comics and painting. The cultural theory has the advantage of forcing us to consider gesture at the moment that it is being exploited, and we will be attentive to this aspect. But today's intense world of communication gives these phenomena a diffuse, confused character which our colleagues take pleasure in glorifying. In this modern context, the expressive gestures that interest us, lose their intelligibility. In order to study their place among the 'symbolic forms' of representation of the Renaissance, it is in our interest not to ignore certain historical texts.

The oldest and most remarkable of these treatises is by a jurist and court advisor from Treviso, Giovanni Bonifacio: L'arte di cenni, con la quale formandosi favella visibile, si tratta della muta eloquenza, che non è altro che un facondo silenzio. ${ }^{7}$ The title states quite clearly the subject of the work: 'the art of gesture, which having formed a visible language, is treated as mute eloquence, or in other words a garrulous silence'. The 'precious' inversion underlines the intention not to study the phenomenon of 'expressive gesture' - this is not at all the subject but to pursue the repertory of body language that bears messages and that is thus apt to be assimilated into a sort of coherent 'para-language' or, better still, a rhetoric of non-verbal communication. The dedication specifies, 'for princes who, because of their dignity, make themselves understood through signs rather than words'. 


\section{0 / Renaissance and Reformation}

In this book, the bodily cenni, these signa membrorum, number more than six hundred; it is a generalized physiognomy in which all points of the body are given equal consideration - forehead, beard, teeth, navel, even the genitals. It is a semiology of the entire body with, as a complement, a treatment of voluntary movements, the calculated gesture, whose classic example is fare altrui la corna, that is, 'raccogliere e col dito pollice premere il medio e l'anellare spingendo l'indice e l'auricolare contro alcuno' ('lower and hold against the thumb the middle and ring finger while pointing the index and little finger in someone's direction'). It is, of course, 'un gesto d'ingiuria, accenando che egli sia una bestia e un becco' ('an insulting gesture indicating that he is a stupid person and a cuckold'). The gesture is as well-known today as in yesteryears - at least in Italy. But we do not find it represented frequently in painting; it belongs to a popular, familiar repertory that encompasses caricature and farce, well illustrated by Callot (fig. 5).

Another exceptional work is that of the astonishing Andrea di Jorio, La mimica degli antichi investigata nel gestire napoletano. ${ }^{8}$ The book is composed of rather ingenious analytical rubrics. The thesis is simple: the Neopolitan, mindful above all of expression, is a total mimic: 'nulla si lascia intentato, ogni parte del corpo concorre all'azione, mani, piedi,

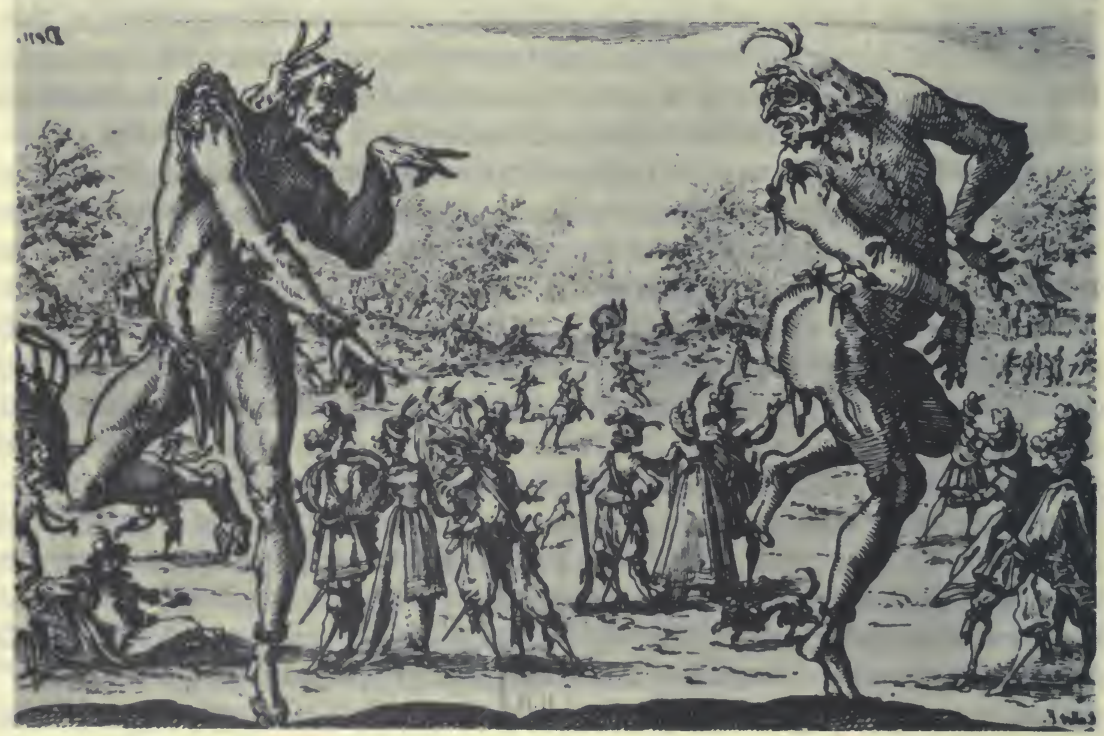

Fig. 5: Callot, Two Pantalons, etching 1617 
capo, occhi; tutto è in moto per l'oggetto' ('among all the parts of the body none remains unused, the hands, the feet, the head and the eyes unite in action; everything is in motion for the final purpose'). The behaviour of the crowd during festivals and ceremonies is sufficient to bring to mind analogies with descriptions and scenes found on ancient monuments. Revelers, weepers, ham actors, are seen every day in the streets of Naples. Jorio's conclusion is that antiquity is to be studied in Italy, and especially in the South. The painter Gigante drew the illustrations which make Jorio's work so valuable; they have since been frequently reused - in Wundt's Gebärdensprache, cited earlier, for exampleand they often reappear in publications of customs, habits and theatre. Except in some simple, general cases - a mimicry of suffering, of mocking - the correspondence with antiquity is evidently very approximate. The diachronic perspective can and must intervene at each stage of our studies.

In adopting the term 'symbolic form' to designate the realm of representation in general, that is to say that infinite ensemble of statues, reliefs, paintings, drawings with figural content, I want above all to recall that the making of every image is subject to certain conditions. As Meyer Schapiro has shown so well, ${ }^{9}$ even the most modest of these, such as format, frame, material support, have their importance. All the more important are requisites of the composition, the laws of genres, the adaptation of forms to the general scheme of composition and the selection of gestures. Regardless of the historical period of the works he examined, we understand Darwin's disappointment. Instead of finding fresh life-like material, he encountered polished movements, arranged according to somewhat eccentric principles, treated much like plants in the hands of a gardner.

Approaching the problem from a different angle, I wonder now if expressive gestures in the 'cultural' definition - that is to say, governed by a conventional code and easy to illustrate - have not lost an important aspect of their function. Each refers totally to the message which locks it into the communication network; yet, if we consider certain key gestures, one wonders if their representation has not been a way of giving them consistency, coherence and continuity through the ages. In other words, as much as it is a consequence, an effect of the conventional definition, the image is perhaps in certain cases one of the factors that insures the authority of this definition. Of course, we are speaking here of primordial forms, of exceptional gestures, such as representations of the Pantocrator, of those large images of the cosmic divinity, of the Logos type, studied long ago by L'Orange. ${ }^{10}$ (fig. 6) All these images are conceived 


\section{2 / Renaissance and Reformation}

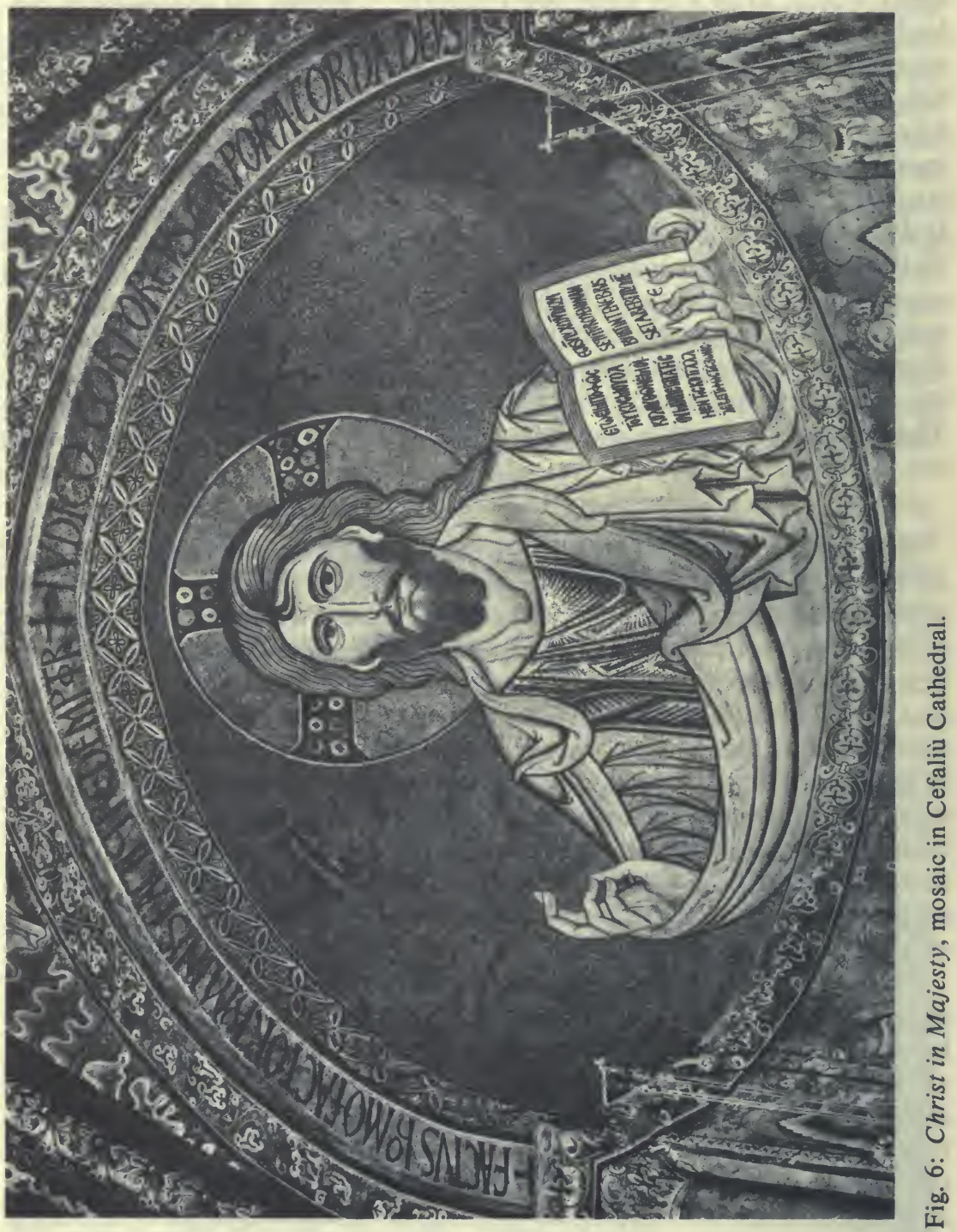


as the exaltation of a symbolic gesture which dominates and even occupies the space of the sanctuary. This circumstance helps us to focus clearly on the problem.

I am starting, then, from Ernst Gombrich's observation that 'the ritualized gestures of prayer, of greeting, of mourning at funeral rites, of teaching or triumph are among the first to be represented in art." ${ }^{11}$ How striking it is that the fundamental signs - divinity, prayers, glorifications - of religion and power are manifested from the outset and together in both ritual and representation. It is as if art-sculpture, mosaic, ceramic, etc. - had as a primordial function to present, perpetuate, impose and teach these primordial signs which we virtually never encounter anywhere else. The reason for this is that the sanctuaries, where ritual developed these essential gestures in concreto, were also the places calling for their representation, places where statuettes, ex votos and souvenirs flourished. The image of the god encompasses the movement necessary to characterize it. A gesture in this context appears as an attribute which completes the stereotype. It would not be absurd to consider these forms as a kind of religious ars memoriae.

In contrast to these hieratic postures, the will to narration, that is to say, the need to illustrate familiar tales or epics, ought to be-we are told - at the roots of naturalist representation. The depiction of mythology requires a new repertory of gestures, close to mimicry: the history of Greek art, especially on vases, which transmits a reflection of painted compositions, provides all the testimony we could wish for. All the more so, since the technique of silhouette gives a marvellously sharp definition to attitudes and movements.

In stylizing human forms, the Greek artist gives us the impression of grasping real life, of confronting actual experience. But this is the illusion of the artist's success, for in fact by vigorously larding the repertory of the fable with the everyday and even the intimate, the painter-ceramicist has initiated a new codification of gestures. This is of extreme importance, because these descriptive operations generate the code of gestural motifs: movements characteristic of trades, everyday signs of welcome or of hostility, and so forth. These indications hold just as true for Renaissance culture as they do for early and late antiquity. The gestures that attract the painter are repeated stereotypes constructed and codified from daily life.

In short, we can state that gestural representation in hieratic poses stems from the sacred, while that in narrative derives from the profane (or, more exactly: the aspects of mimetics structured in experience, to use the words of Michael Baxandall. ${ }^{12}$ ) Both types welcome gestures whose very representation contributes to their preservation. In the first case, we find an echo in the liturgy; in the second in the theatre, the 


\section{4 / Renaissance and Reformation}

pantomine, and of course in the art of rhetoric. From the time of Cicero and Quintilian, the realm of oratory has been equipped with instituted gestures, well studied and transmitted to the present. ${ }^{13}$ Thus it is possible, little by little, to identify the 'system' and, more simply, the repertory offered by the figural documents.

However, I must limit my analysis to a few special cases of widely depicted gestures that have played an important part in our civilisation and whose particular use during the Renaissance is likely to be of interest. They are the gestures of prayer, of silence, and of admonition. They illustrate the pervasive role of the hand in our study.

A masterful study has charted the course of one of the fundamental religious gestures, that of prayer. The joining of hands or stretching out of arms is not a reflex movement; it is found universally only as a sign of subjugation, as in the case of a prisoner or of a vassal. In Christian liturgy, prayer is expressed by the spreading of the arms in the orant gesture, an attitude assumed no less than five times during the Roman Catholic mass. It was partially replaced in the thirteenth century, during the papacy of Gregory IX, by the prayer manibus junctis, whose success seems to have been stimulated simultaneously by Franciscan pressure and by the analogy with the feudal recommandatio. The Franciscan ordo missae instructs that the elevation of the host - the supreme moment of the holy office - be made junctis manibus; in order to offer Christ's body to God in a worthy fashion, one must concentrate and be wholly collected. Similarly, the vassal places his hands in those of his overlord, like a captive, in order to receive the title he is being conferred. Although a late conception, the junctio manuum constitutes one of the complex moments, one of the high-water marks in the mediaeval code. Its pictorial representations have been indispensable for reconstructing its evolution and meaning. ${ }^{14}$

The result of this development, which naturally has many other aspects, was the specifying of a religious meaning for one of the actions of the hand. It is not pure chance that some images of this gesture in the works of Albrecht Dürer and later of Rodin, have a particularly moving value. This illustrates a remarkable tendency for such a gesture: that the ebb and flow of experience and representation should impart emblematic value. The symbolic motion tends to turn inwards on itself. A concerted movement of the entire body is manifested in the kneeling figure stretching out his hands; from there, we pass to the outstretched arm, which is sufficiently explicit if the hands are united; and finally to the hands detached from the body which, isolated, become a powerful signifying object by virtue of a visual metonymy easily explained by the primacy of the hands.

A similar development of symbolic movement is evident in the two 
other gestures that I would like to discuss. Both are linked to the play of those masterful actors, our fingers, and in particular to the most active, the most ambitious of all, the index. Sometimes they engage the entire body in a specific attitude; sometimes everything focuses on the palm and the finger.

One gesture with a well-attested symbolic function is the gesture of silence, the signum harpocraticum. This apparently explicit motif has endless human and religious implications. We find it in the image of the model monk by Giotto and by Fra Angelico (St. Peter Martyr, Monastery of S. Marco, Florence), where it fills the entire composition (fig. 7). It is found, moreover, in earlier decorative medallions. But what exactly is its significance? Is it asking for silence from the spectator? Or is it reminding us that we are in a holy place, San Marco, spiritually governed by the silence of the interior life? We have examples of the passive meaning, 'I am silent' - and therefore obedient - and of the active meaning, 'Be quiet.' The first seems to go back to Gnostic imagery where the mouth is closed to prevent the entry of the devil. The second is associated with Egypt and the Sphinx; Ovid says that the figure placed before the sanctuary digito silentia suadet ${ }^{15}$

It is only in the post-Renaissance world that the signum has eventually taken on a licentious accent - in the scenes galantes, such as Temptation by Pietro Longhi - or, later, a funereal value; in the third chapter of The Magic Mountain, Thomas Mann describes the visit to a cemetery where he sees 'a little angel or putto in stone who had a bonnet made of snow ... and a finger closing its lips... [and who] could have been passed off as the genius of this silence'.

Erwin Panofsky interpreted Michelangelo's famous gesture of the pensieroso Lorenzo de' Medici (fig. 8) as 'the gesture of saturnian silence. ${ }^{16}$ For me this is not a signum silentii, but rather the nonchalant attitude of the melancholic dreamer, the hand on the chin, which is rather like Degas' Woman with Chrysanthemum (1865, Metropolitan Museum of Art, N.Y.), or people in an audience. The signum harpocraticum is not saturnine but hermetic. One finds it associated in the Quaestiones of Achille Bocchi ${ }^{17}$ with the god of eloquence, a paradoxical encounter which has emblematic value: the praise of discourse associated with that of secrecy, a constant preoccupation, as we know, of the Renaissance. And it is perhaps here that we may find a way of resolving the enigma of the strange and brilliant painting by Dosso Dossi. (Vienna, Kunsthistorische Museum; fig. 9) While Jupiter paints butterflies (a parable of the creation of souls, it seems), a Virtue tries to attract his attention, but Mercury pushes her away. She is Eloquentia, the art of discourse, and she would like to intervene in the creative act of the god. But all is accomplished thanks to Painting alone. The rivalry between 
16 / Renaissance and Reformation

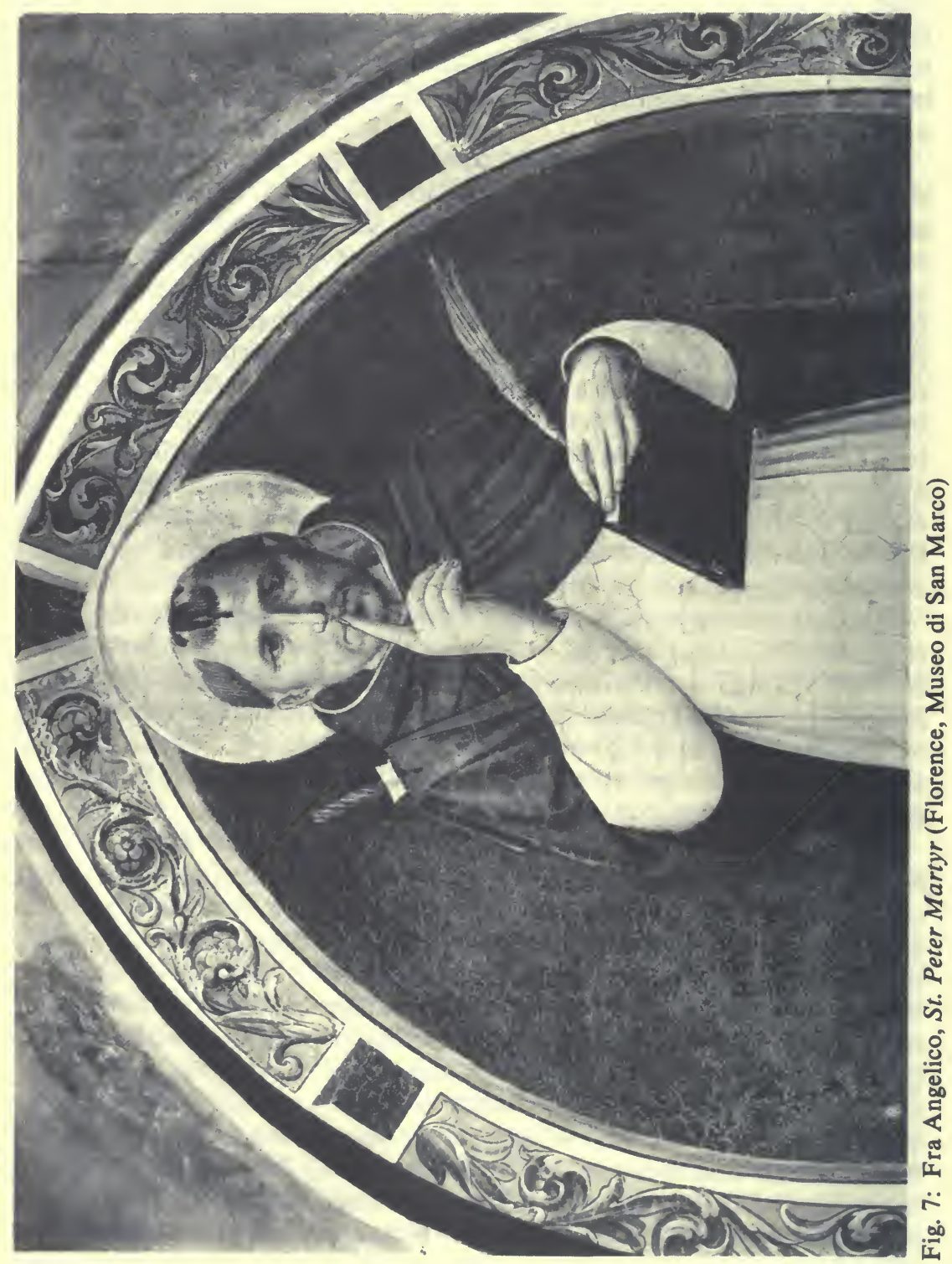




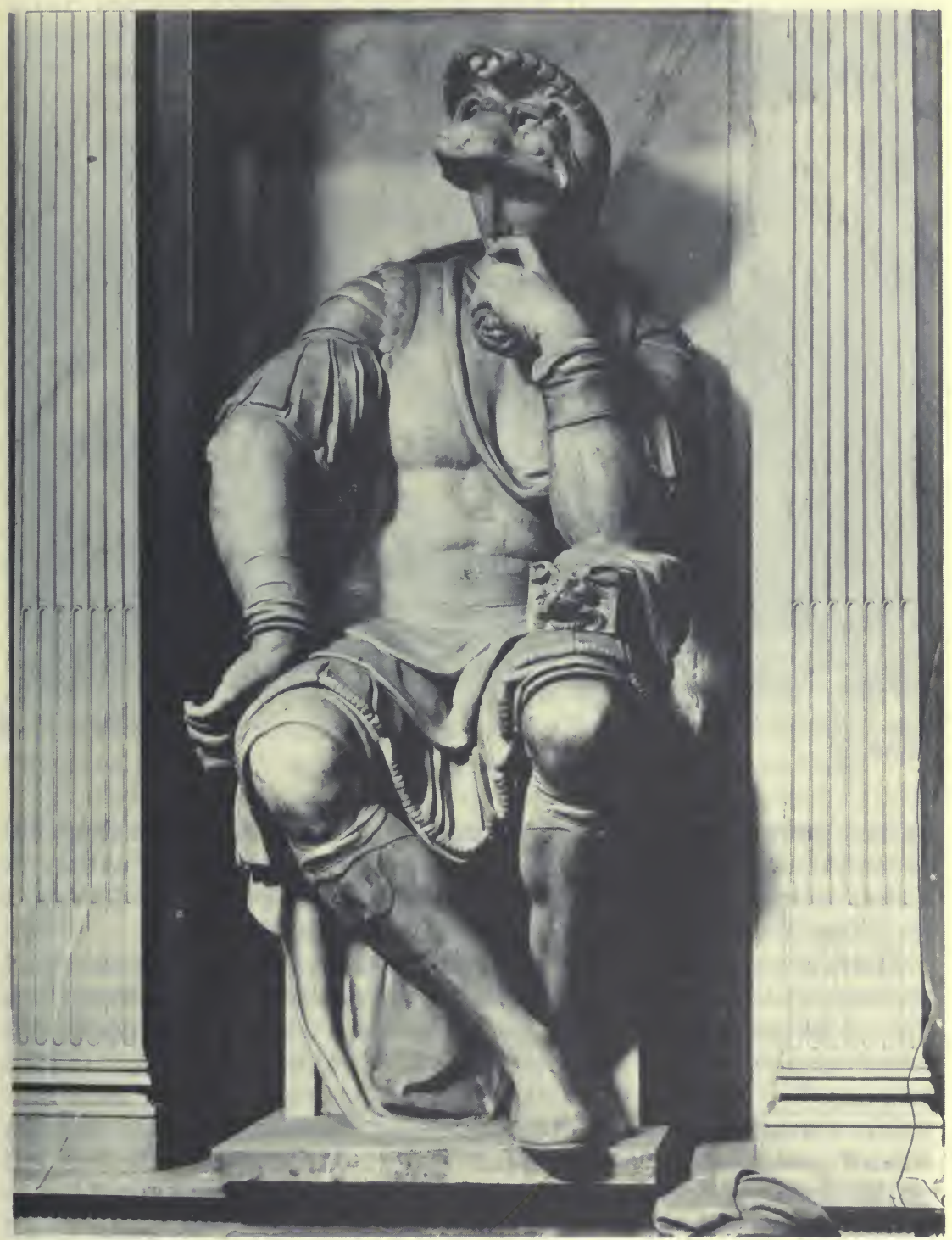

Fig. 8: Michelangelo, Lorenzo de' Medici (Florence, San Lorenzo, Medici Chapel) 


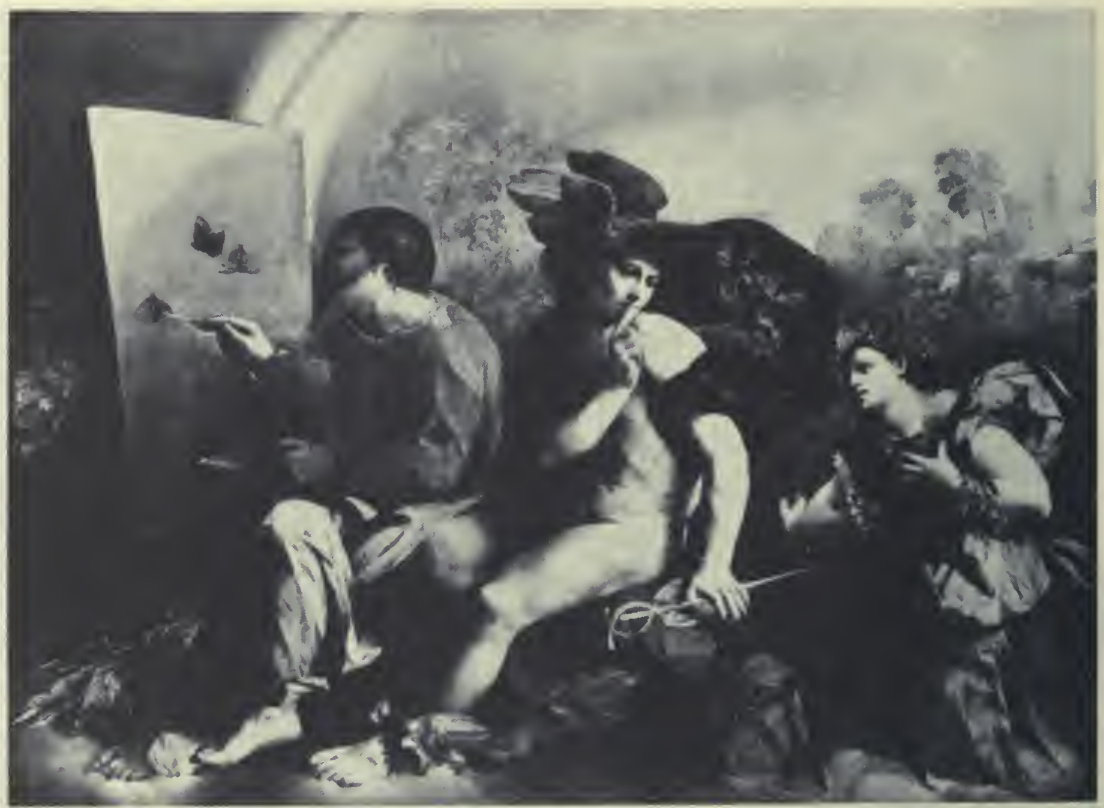

Fig. 9: Dosso Dossi, Jupiter, Mercury and Eloquentia (Vienna, Kunsthistorische Museum)

literary power and art form a backdrop to this allegory. The analogy between the present situation, where the linguistic model vies with nonverbal ones, is so striking that I thought for a long time that I was the plaything of an illusion in proposing this 'reading.'

There is a gesture much used in painting, as in theatre, which in fact appears still more often in the depicted than in the experiential world; it is that of the pointed index. Its use is far more widespread than even I imagined. Let us, as a conclusion, try to explore its usefulness for our purpose. ${ }^{18}$

It is essentially a gesture of admonition, the one that Leon Battista Alberti recommends: 'Tum placet in historia adesse quempiam qui earum quae gerantur rerum spectatores admoneat, aut manu ad visendum advocet ... ' ('Then, I like there to be someone in the picture who tells the spectators what is going on, and . . . beckons them with his hand to look'). ${ }^{19}$ The closest example - and one of the most powerful-is found in the Trinity by Masaccio(Santa Maria Novella, 1425), where one sees how this gesture is conceived: the index designates the object and the gaze of the admonisher searches out that of the spectator. This combination 
is very ancient: a Roman mosaic (Museo di Termi) uses it as a schematic, philosophical memento mori. Such is the power of this gesture that it can be reduced to the hand alone and the pointing finger. The 'admonishers' of Pordenone in the Crucifixion in Cremona (1520), of Bedoli Mazzola in the Immaculate Conception in Parma (1533) challenge the spectator like the figures on modern posters. This specialized gesture, in a sense, vindicates those who refuse to accord special attention to the arts of information-giving.

In fact, this indicative trait plays a decisive role in many important compositions: accompanied by the gaze, it creates an impressive line of strength in Titian's Madonna d'Ancona; enhanced in a beam of light, it creates a gripping effect in the Calling of Matthew by Caravaggio (Rome, S. Luigi dei Francesi). It is beyond question that painting, silent poetry as it is called, finds here a perfect way of compensating for the spoken word. But there is another use of the pointing gesture that cannot be forgotten; it is its reference to the sacred. Leonardo da Vinci used it in a very personal way, as we know. The angel in the Virgin of the Rocks (London, National Gallery of Art) plays the role of the Albertian admonisher; but that pointed index reappears with a quasi-emblematic value in the Precursor, or Baptist (Paris, Louvre; fig. 10). Henceforth, the gesture of the index is inevitable in depictions of the Baptist, designating the Child or a phylactery. Leonardo's Baptist points toward the sky, taking on a generalized meaning, of which Pablo Picasso ironically remarked, 'Yes, da Vinci promises heaven: look at this raised finger.'20

Leonardo has led us toward the key terms. The word moto with its double meaning is the sought-after response: visible movement and hidden emotion. Alberti was content to say, ' . . . sui motus corporis ad eos quos velis exprimere motus animi referantur' ('each person's bodily movements ... should be related to the emotions you wish to express'). ${ }^{21}$ Leonardo went further: when studying 'l'omo e il concetto della mente sua,' he says, 'the good painter has essentially two things to represent: the person and the content of his thought' ${ }^{22}$ Herein lies the program of a painting where the painted figure is not present in order to represent a condition, a quality, but rather a being. In order to succeed there is but one solution: 'this is done through the aid of gestures and movements of the body's members.' And to that end one must endlessly observe and note down what is representable in the living spectacle of people. With his habitual intrepidness, Leonardo envisioned a human world in which the spoken word melted away (as when one witnesses a conversation through a glass) and all that remained was the art of mime. By collecting the necessary motifs, one would have the means to create compositions where language would be totally replaced by gestures. The unfinished Adoration of the Magi (Florence, Uffizi) has always been considered a 
20 / Renaissance and Reformation

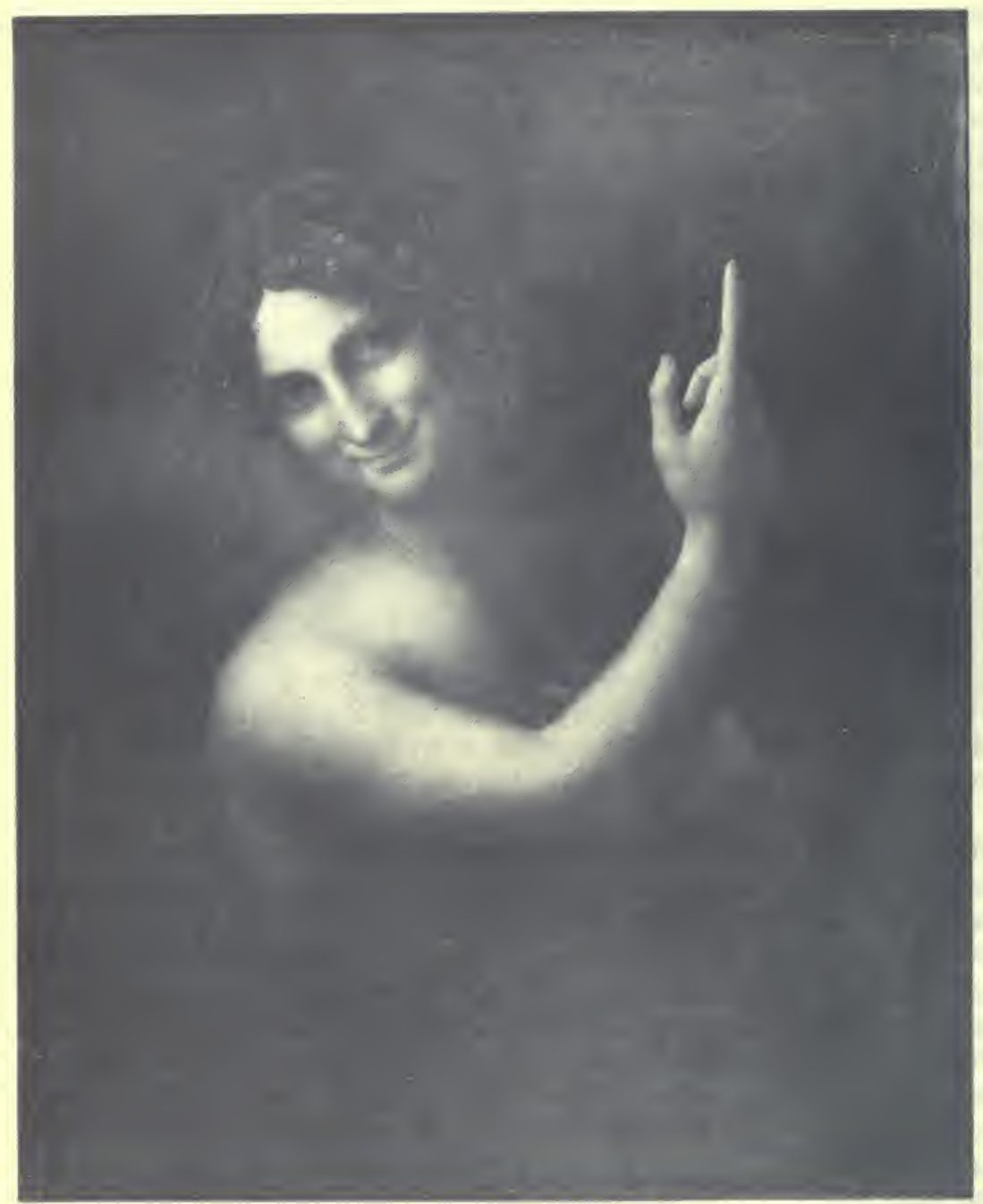

Fig. 10: Leonardo, St. Jean the Baptist (Paris, Louvre) 
manifesto of that concept, and the Last Supper (Milan 1495-7) - with the intense action of its one hundred and thirty fingers - its masterpiece. This principle, this programme, these renderings constituted a revolution without precedent.

In general terms, the expressive gesture, in the double register of the repertory, had previously played a role which one could describe as mnemotechnical. The composition of Dirk Bouts (fig. 3) or of Ghirlandaio is a compilation, an adjustment of adapted signs: it is a corona of attitudes and gestures, devoid of psychological value. In Leonardo's Adoration of the Magi these signs are suddenly enriched with a troubling psychological dimension. The Last Supper shows a turmoil of expressive gesture of great intensity. Even a secondary personnage is no longer a simple bearer of a gesture useful to the composition; he is abruptly endowed with his own reality. Whence followed a series of complications which, by their very enrichment, progressively paralized the inventiveness of Leonardo. The only one who was able to react to that terrible exigency (without succumbing to painful confusion was the young Raphael. The Parnassus (Vatican, Stanza della Segnatura) and the School of Athens (Vatican, Stanza d'Eliodoro) are compositions of controlled gestures. Or, to take the simplest example, observe the astonishing modulations of the moti in the Miraculous Draught of the Fishes, one of the famous tapestries conceived for the Sistine Chapel. Are all of these susceptible to precise interpretation? I rather doubt it because the institutionalized content of ritualized gesture is being supplanted by a more spontaneous, naturalist gesture; but the semantic naïveté of gesture is compromised by a learned interest in the moti, which prepares the academic codification of the Seicento.

Collège de France, Paris.

\section{Notes}

1 Giovan Pietro Bellori Le vite de' pittori, scultori e architetti moderni (Rome 1672) 205.

2 Charles Darwin The Expression of Emotions in Man and Animals (London 1872).

3 W. Wundt Wölker-psychologie (Leipzig 1912); English trans. The Language of Gestures (The Hague 1973).

4 S. Reinach 'L'Histoire des gestes' in Revue archéologique, 20 (1924) 64-79.

5 D. Morris Man Watching. A Field to Human Behaviour (London and New York 1977).

6 Non Verbal Communication, ed. R.A. Hinde (Cambridge 1972), 373 sgg. The essay by E.H. Gombrich, 'Action and expression in Western art,' now in The Image and the Eye (London 1982) 105 sgg. See also: S. Settis 'Immagini della meditazione, dell'incertezza e del pentimento nell'arte antica' in Prospettiva (1975) 2:4 sgg.

7 G. Bonifacio L'arte dei cenni ... . (Vicenza 1616). See B. Croce 'Il linguaggio dei gesti' in La Critica 29 (1931) 223 sgg.

8 Andrea di Jorio La mimica degli antichi investigata nel gestire napoletano (Naples 1832). 


\section{2 / Renaissance and Reformation}

9 M. Schapiro 'On Some Problems in the Semiotics of Visual Art: Field and Vehicle in Imagesigns' in Semiotica 1 (1969) 3:223 sgg.

10 H.R. L'Orange Studies on the Iconography of Cosmic Kingship in the Ancient World, Instituttet for Sammenlinguende Kulturforskning, XXIII, (Oslo 1953) chapt. 17: 'The Gesture of Thought. The Sign of Logos.'

11 E. Gombrich 'Ritualized Gesture and Expression in Art' in Philosphical Transactions of the Royal Society of London 251 (1966), 393-401, now in The Image and the Eye, 63 sgg.

12 M. Baxandall Painting and Experience in Fifteenth Century Italy (London, Oxford and New York 1972).

13 On the importance of Quintilianus' Institutiones oratoriae libri XII, XI, 3, for modern 'art of gestures' see G. Heinz 'Realismus und Rhetorik im Werk des Bartolomeo Passarotti' in Jahrbuch der kunsthistorischen Sammlungen in Wien 68 (1972) 153 sgg.

14 G. Ladner 'The Gesture of Prayer in Papal Iconography of the XIIIth and early XIVth Century' in Didascaliae. Studies in Honour of Anselm M. Albareda, ed. Sesto Prate (New York 1961) 153 sgg.

15 Met. IX, 962. See K. Langedijk 'Silentium' in Nederlands kunsthistorisch Jaarboek 15 (1964) 3 sgg.

16 E. Panofsky Studies in Iconology (Oxford 1939) 211.

17 Achille Bocchi Symbolicarum quaestionum de universo genere (Bologna 1555). See E. Wind Pagan Mysteries in the Renaissance (London 1958) 19 sgg, fig. 21.

18 J.J. Tikkanen 'Zwei Gebärden mit den Zeigefinger' in Acta Societatis Scientiarum Finnicae (Helsinki) 43 (1913); A. Chastel 'Sémantique de l'index' in Storia dell'Arte 38/40 (1980) 3739.

19 Leon Battista Alberti De pictura, ed. and trans. by Cecil Grayson (New York 1972), 2:803.

20 D. Ashton Picasso on Art (New York 1972) 168.

21 Alberti, II, 84-5

22 C.U. 60 v. See Leonardo da Vinci, Codex Urbinas Latinus 1270 (Vatican Library), Part III: Of the Various States and Movements of the Human Body, trans. A. Philip McMahon, 2 vol (Princeton 1956) n. 248 and the following texts. 